\title{
Detection by PCR of hepatopancreatic parvovirus (HPV) and other viruses in hatchery-reared Penaeus monodon postlarvae
}

\author{
Rudrappa K. Umesha ${ }^{1}$, Arumugam Uma ${ }^{2}$, Subhendu K. Otta ${ }^{1}$, Indrani Karunasagar ${ }^{1, *}$, \\ Iddya Karunasagar $^{1}$ \\ ${ }^{1}$ Department of Fishery Microbiology, University of Agricultural Sciences, College of Fisheries, Mangalore 575 002, India \\ ${ }^{2}$ Shrimp Disease Diagnosis Laboratory, Tamilnadu Veterinary and Animal Sciences University, Madhavaram Milk Colony, \\ Chennai-600051, India
}

\begin{abstract}
The prevalence of hepatopancreatic parvovirus (HPV), monodon baculovirus (MBV) and white spot syndrome virus (WSSV) in samples of Penaeus monodon postlarvae (PL10 to PL20, 10 to $20 \mathrm{~d}$ old postlarvae) in India was studied by PCR. Samples collected from different hatcheries, and also samples submitted by farmers from different coastal states, were analyzed. HPV was detected in $34 \%$ of the hatchery samples and $31 \%$ of the samples submitted by farmers, using a primer set designed for detection of HPV from P. monodon in Thailand. However, none of these samples were positive using primers designed for detection of HPV from $P$. chinensis in Korea. This indicated that HPV from India was more closely related to HPV from P. monodon in Thailand. MBV was detected in $64 \%$ of the samples submitted by the farmers and $71 \%$ of the hatchery samples. A total of $84 \%$ of the samples submitted by farmers, and $91 \%$ of the hatchery samples, were found positive for WSSV. Prevalence of concurrent infections by HPV, MBV and WSSV was $27 \%$ in hatchery samples and $29 \%$ in samples submitted by farmers. Only $8 \%$ of the hatchery samples and $16 \%$ of the samples submitted by farmers were negative for all 3 viruses. This is the first report on the prevalence of HPV in $P$. monodon postlarvae from India.
\end{abstract}

KEY WORDS: HPV $\cdot \mathrm{MBV} \cdot \mathrm{WSSV} \cdot \mathrm{PCR} \cdot$ Penaeus monodon $\cdot$ Postlarvae $\cdot \mathrm{HPVmon}$

\section{INTRODUCTION}

Viral diseases have become an important limiting factor for the shrimp aquaculture industry throughout the world. The use of monoculture stocks and high stocking densities encourages the development and transmission of many diseases within the cultured populations (Lightner 1993). About 22 different viruses are known to infect shrimp, and several of them have been associated with mass mortalities in cultured shrimp (Hsu et al. 2000).

Hepatopancreatic parvovirus (HPV) was first reported in Penaeus merguiensis and $P$. indicus
(Chong \& Loh 1984) and in postlarvae (PL) of P. chinensis (Lightner \& Redman 1985). It infects several species of penaeid shrimp and is widely distributed in many parts of the world (Lightner 1996). HPV-infected shrimp do not show specific gross signs of disease, but heavy infection results in stunted growth of $P$. monodon (Flegel et al. 1999). In India, the presence of HPV in hatchery-reared PL, and the heavy mortality of PL due to this virus, along with monodon baculovirus (MBV) and white spot syndrome virus (WSSV), has been reported by Manivannan et al. (2002).

Monodon baculovirus (MBV) was implicated in the collapse of the Taiwanese shrimp farming industry in 
1987/88 (Lin 1989). In India, larval mortalities in hatcheries due to MBV have been recorded by Ramasamy et al. (1995), and similar catastrophic mortalities have been recorded in Malaysia (Nash et al. 1988) and Thailand (Thikiew 1990). Simultaneous occurrence of MBV with WSSV in apparently healthy $P$. monodon PL in India was found by Otta et al. (2003).

Recently, WSSV has emerged as one of the most serious disease problems in cultured shrimp populations all over the world. It affects all of the most important commercial species of penaeid shrimp (Lightner 1996). Wild marine shrimp and many cultured and captured crustaceans have also been found to harbor this virus (Hossain et al. 2001, Chakraborty et al. 2002).

The presence of WSSV in Penaeus monodon PL in India was reported by Otta et al. (1999). Although simultaneous detection of WSSV and MBV in apparently healthy $P$. monodon PL was reported by Otta et al. (2003), there is no report on the presence of HPV in healthy larvae. In this context, the present study was carried out to screen for all 3 aforementioned viruses by PCR, both in samples of hatchery-reared PL collected by us, and in samples submitted by farmers.

\section{MATERIALS AND METHODS}

Sample collection. PL (PL10 to PL20) of Penaeus monodon were collected from different hatcheries located on the east and west coasts of India from May to December 2002. From the east coast, 20 samples were collected from 10 hatcheries ( 2 tanks per hatchery), and on the west coast, 75 samples were collected from 12 hatcheries (6 to 7 tanks per hatchery). A minimum of 150 to 200 PL were collected from the 4 corners and center of each tank, which contained approximately 1000000 PL, and brought live to the laboratory in oxygenated bags. In addition, 107 samples of PL10 to PL20 submitted by farmers from different coastal states were included in the study.

Extraction of DNA. From the 150 to 200 PL collected, 30 were subsampled for DNA extraction. This number was based on our preliminary studies indicating the inhibitory effect of excess shrimp DNA on PCR. Total DNA was extracted as described by Otta et al. (2003) and employed for PCR detection of HPV, MBV and WSSV.

PCR analysis. Two sets of primers were used for the detection of HPV. The PCR protocol and primer set (H441F and H441R) described by Phromjai et al. (2002) was expected to yield a product of $441 \mathrm{bp}$, while the protocol and primer set $1120 \mathrm{~F}$ and $1120 \mathrm{R}$ described by Pantoja \& Lightner (2000) was expected to yield a product of $592 \mathrm{bp}$. For the detection of MBV, the nested PCR primers and protocol described by Belcher \&
Young (1998) were employed. A nested PCR protocol (Hossain et al. 2001) was also used for WSSV detection. PCR was carried out in a $30 \mu$ reaction mixture consisting of: $1 \times$ PCR buffer; 5 pmol of each primer for HPV and WSSV, and 10 pmol of each primer for MBV; $50 \mu \mathrm{M}$ each of dATP, dCTP, dGTP and dTTP; $0.9 \mathrm{U}$ of Taq DNA polymerase; and $2 \mu \mathrm{l}$ of DNA extract. Total DNA extracted from shrimp showing histopathological changes characteristic of WSSV, MBV and HPV were used as templates for positive controls, and DNA extracted from healthy freshwater fish Labeo rohita was used as the template for the negative control. Amplification was carried out in a thermocycler (M. J. Research). The amplified PCR products were electrophoresed in a $1.2 \%$ agarose gel containing $0.5 \mu \mathrm{g}$ $\mathrm{ml}^{-1}$ ethidium bromide, and visualized with a UVtransilluminator (Gel doc system, Hero Lab).

\section{RESULTS AND DISCUSSION}

Of 95 postlarval Penaeus monodon samples collected directly from hatcheries located along the east and west coasts of India, $32(34 \%)$ were positive for HPV, using the primer set for P. monodon HPV from Thailand described by Phromjai et al. (2002) (Table 1).

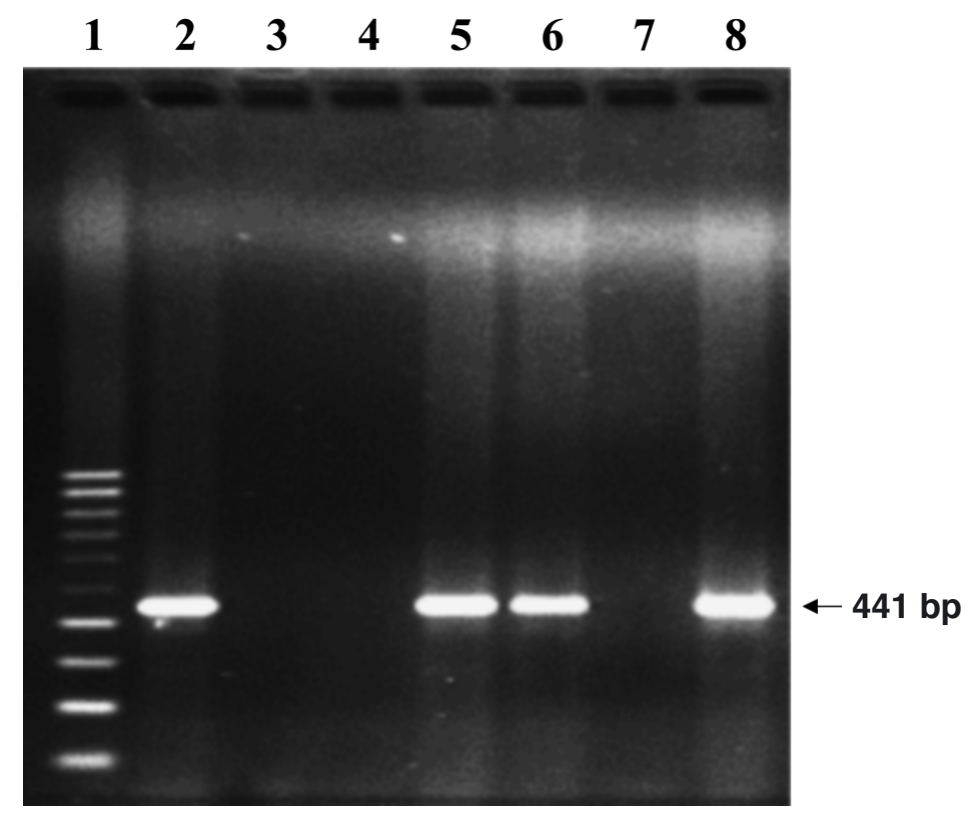

Fig. 1. Penaeus monodon. Sample electrophoresis gel for detection of hepatopancreatic parvovirus (HPV)-specific PCR amplicons using the primer set of Promjai et al. (2002) with hatcheryreared postlarvae (PL10 to PL20). Arrow indicates size of the product obtained. Lane 1: $100 \mathrm{bp}$ DNA ladder; Lane 2: positive control; Lane 3: negative control; Lanes 4 \& 7: HPV not detected; Lane 5, 6 \& 8: HPV detected 
Table 1. Penaeus monodon. Prevalence of hepatopancreatic parvovirus (HPV), monodon baculovirus (MBV) and white spot syndrome virus (WSSV) detected by PCR in hatchery-reared PL in India

\begin{tabular}{|c|c|c|c|c|c|c|c|c|}
\hline \multirow[t]{2}{*}{ Location } & \multirow{2}{*}{$\begin{array}{l}\text { No. samples } \\
\text { analysed }\end{array}$} & \multirow{2}{*}{$\begin{array}{l}\text { No. positive } \\
\text { for HPV }\end{array}$} & \multicolumn{3}{|c|}{ No. positive for MBV } & \multicolumn{3}{|c|}{ No. positive for WSSV } \\
\hline & & & Non-nested & Nested & Total & Non-nested & Nested & Total \\
\hline East coast & 20 & 17 & 5 & 15 & 20 & 8 & 12 & 20 \\
\hline West coast & 75 & 15 & 11 & 36 & 47 & 15 & 51 & 66 \\
\hline Total & 95 & $\begin{array}{c}32 \\
(34 \%)\end{array}$ & $\begin{array}{c}16 \\
(17 \%)\end{array}$ & $\begin{array}{c}51 \\
(54 \%)\end{array}$ & $\begin{array}{c}67 \\
(71 \%)\end{array}$ & $\begin{array}{c}23 \\
(24 \%)\end{array}$ & $\begin{array}{c}63 \\
(66 \%)\end{array}$ & $\begin{array}{c}86 \\
(91 \%)\end{array}$ \\
\hline
\end{tabular}

Table 2. Penaeus monodon. Prevalence of hepatopancreatic parvovirus (HPV), monodon baculovirus (MBV) and white spot syndrome virus (WSSV) detected by PCR in samples of PL submitted by farmers from different coastal states

\begin{tabular}{|c|c|c|c|c|c|c|c|c|}
\hline \multirow[t]{2}{*}{ Location } & \multirow{2}{*}{$\begin{array}{l}\text { No. samples } \\
\text { analysed }\end{array}$} & \multirow{2}{*}{$\begin{array}{l}\text { No. positive } \\
\text { for HPV }\end{array}$} & \multicolumn{3}{|c|}{ No. positive for MBV } & \multicolumn{3}{|c|}{ No. positive for WSSV } \\
\hline & & & Non-nested & Nested & Total & Non-nested & Nested & Total \\
\hline Karnataka & 55 & 15 & 6 & 30 & 36 & 5 & 42 & 47 \\
\hline Kerala & 23 & 7 & 3 & 11 & 14 & 2 & 17 & 19 \\
\hline Goa & 10 & 2 & - & 6 & 6 & - & 6 & 6 \\
\hline Maharashtra & 19 & 9 & 2 & 10 & 12 & 3 & 15 & 18 \\
\hline Total & 107 & $\begin{array}{c}33 \\
(31 \%)\end{array}$ & $\begin{array}{c}11 \\
(10 \%)\end{array}$ & $\begin{array}{c}57 \\
(53 \%)\end{array}$ & $\begin{array}{c}68 \\
(64 \%)\end{array}$ & $\begin{array}{c}10 \\
(9 \%)\end{array}$ & $\begin{array}{c}80 \\
(75 \%)\end{array}$ & $\begin{array}{c}90 \\
(84 \%)\end{array}$ \\
\hline
\end{tabular}

(A sample electrophoresis gel is shown in Fig. 1.) Using the same PCR assay with 107 postlarval samples submitted by farmers, 33 (31\%) (Table 2 ) were positive for HPV. However, none of these samples gave positive PCR reactions for HPV when using the primers described by Pantoja \& Lightner (2000) for HPV in $P$. chinensis from Korea. (A sample gel is shown in Fig. 2.) In order to demonstrate that these were not false negative results, the DNA extracts were used as templates for PCR amplification using the shrimp-DNA specific primer-set 143F and 145R described by Lo et al. (1996), which yielded the expected $848 \mathrm{bp}$ product (Fig. 2). Since the DNA sequence of HPV in P. monodon from Thailand (HPVmon) differs from that of HPV in P. chinensis from Korea (HPVchin) by approximately $30 \%$ (Phromjai et al. 2002), our results suggest that HPV from these Indian specimens is more closely related to HPVmon than to HPVchin.

Lightner (1996) and Flegel et al. (1999) reported that HPV infection has the most significant impact in growout ponds, but the present study indicates that HPV infection is also significant in hatchery-reared PL, and that infection may occur at the hatchery via infected broodstock. Few data exist on the prevalence of HPV in hatchery-reared PL. As indicated in Table 2, the prevalence of HPV in Penaeus monodon PL submitted by shrimp farmers $(31 \%)$ was about the same as that from hatcheries $(34 \%)$. A lower prevalence of HPV compared to MBV and WSSV noted in this study could be due to the sensitivity of the tests employed to detect the viruses. While nested PCR was used for WSSV and MBV, only 1-step PCR was used to detect HPV.
As shown in Table 1, 67 (71\%) of the 95 hatchery samples were positive for MBV (16 by non-nested and 51 by nested PCR), and 86 (91\%) were positive for WSSV (23

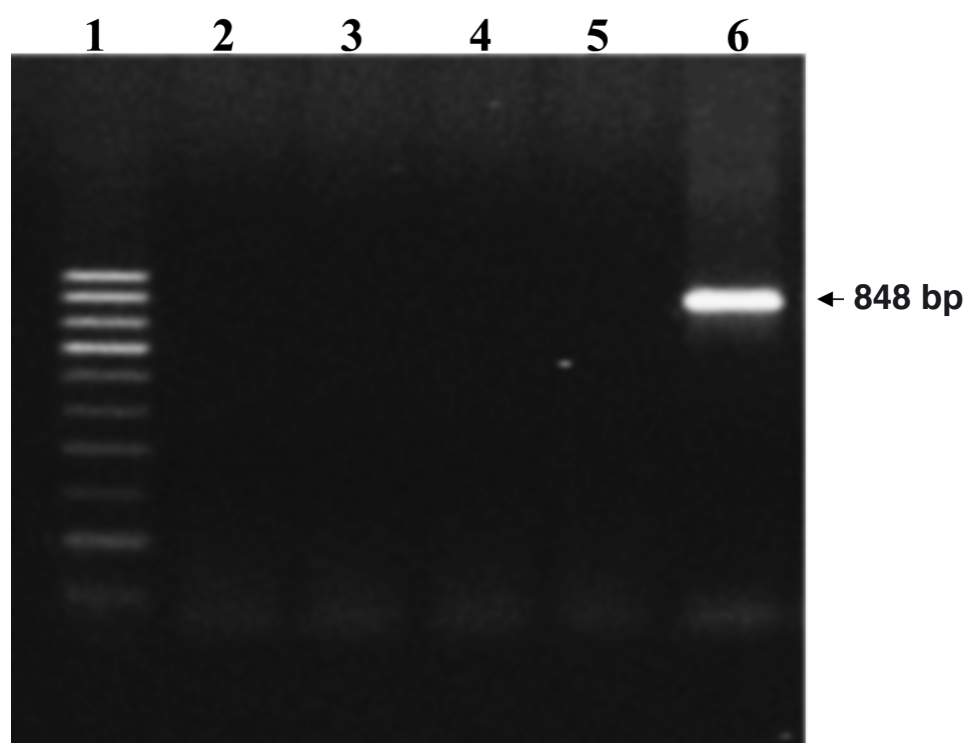

Fig. 2. Penaeus monodon. Sample electrophoresis gel for detection of hepatopancreatic parvovirus (HPV)-specific PCR amplicons using the primer set of Pantoja \& Lightner (2000) with hatchery-reared postlarvae (PL10 to PL20). Arrow indicates size of the product obtained. Lane 1: $100 \mathrm{bp}$ DNA ladder; Lanes 2 \& 3: DNA extract from shrimp showing histopathological evidence of HPV infection; Lane 4: DNA from a shrimp histopathologically negative for HPV; Lane 5: fish DNA; Lane 6: PCR amplification of shrimp DNA using primers reported by Lo et al. (1996) 


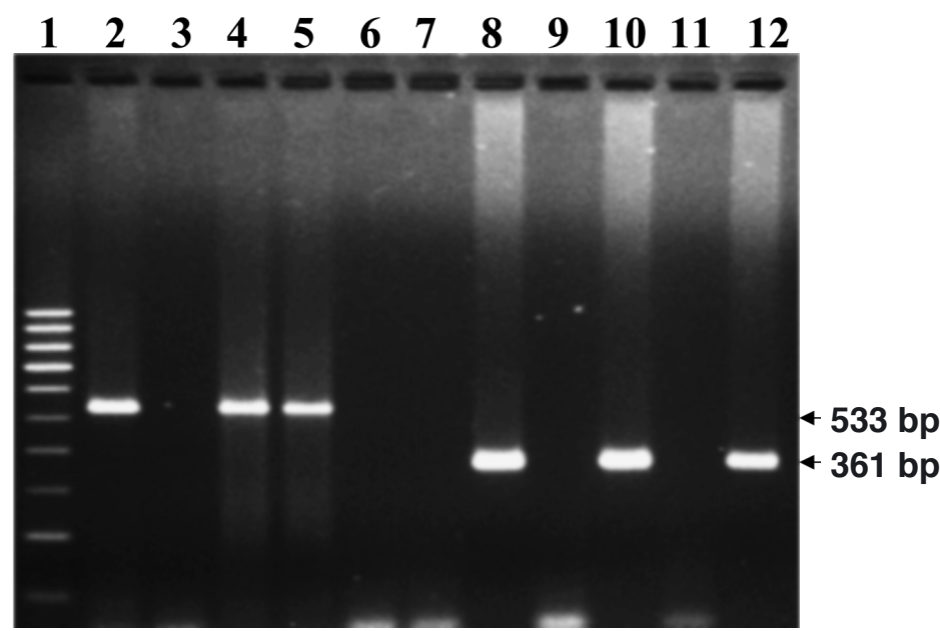

Fig. 3. Penaeus monodon. Sample electrophoresis gel for detection of monodon baculovirus (MBV)-specific PCR amplicons in hatchery-reared PL (PL10 to PL20) by 1-step (Lanes 2 to 7) and nested (Lanes 8 to 12) PCR. Arrows indicate size of the product obtained. Lane 1: 100 bp DNA ladder; Lane 2: positive control for 1-step PCR; Lane 3: negative control; Lanes 4 \& 5: MBV detected by 1-step PCR; Lanes 6 \& 7: MBV 'negative' by 1-step PCR; Lane 8: positive control for nested PCR; Lane 9: negative control; Lanes 10 \& 12: MBV detected by nested PCR; Lane 11: MBV not detected by nested PCR

\section{$\begin{array}{llllllllllll}1 & 2 & 3 & 4 & 5 & 6 & 7 & 8 & 9 & 10 & 11 & 12\end{array}$}

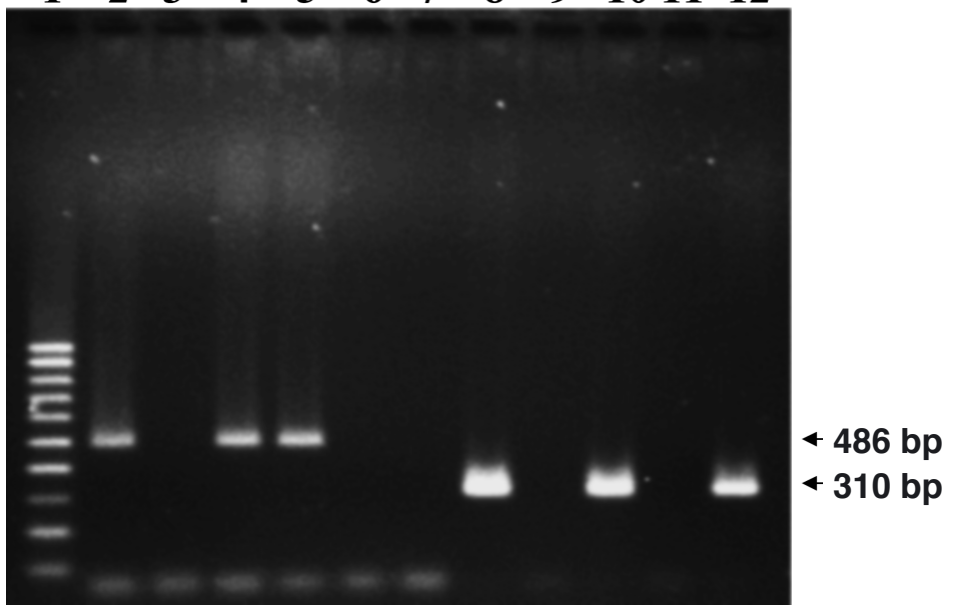

Fig. 4. Penaeus monodon. Sample electrophoresis gel for detection of white spot syndrome virus (WSSV)-specific PCR amplicons in hatchery-reared PL (PL10 to PL20) by 1-step (Lanes 2 to 7 ) and nested (Lanes 8 to 12) PCR. Arrows indicate size of the product obtained. Lane 1: $100 \mathrm{bp}$ DNA ladder; Lane 2: 1-step PCR positive control; Lane 3: negative control; Lanes 4 \& 5: WSSV detected by 1-step PCR; Lanes 6 \& 7 : WSSV 'negative' by 1-step PCR; Lane 8: nested PCR positive control; Lane 9: negative control; Lanes 10 \& 12: WSSV detected by nested PCR; Lane 11: WSSV not detected by nested PCR (healthy larvae) by non-nested and 63 by nested PCR). Of the 107 samples submitted for PCR analysis by farmers (Table 2), 68 (64\%) were positive for MBV (11 by non-nested and 57 by nested PCR) and 90 (84\%) were positive for WSSV (10 by non-nested and 80 by nested PCR). Samples of electrophoresis gels are shown in Figs. $3 \& 4$ (MBV and WSSV, respectively). Such high prevalence of these viruses has been reported earlier (Otta et al. 2003).

With respect to multiple and single viral infections detected in the 95 hatchery samples by PCR (Table 3), 26 (27\%) were positive for all 3 viruses (HPV, MBV and WSSV), 1 (1\%) was positive for HPV and MBV, 3 (3\%) were positive for HPV and WSSV, 21 (22\%) were positive for MBV and WSSV, and $2(2 \%)$ were positive for HPV only. MBV alone was detected in 8 samples (8\%) and WSSV alone in 26 (27\%). No viruses were detected in only $8(8 \%)$ of the 95 samples. PCR analysis for multiple and single viral infections in 107 samples submitted by farmers (Table 4) revealed that $31(29 \%)$ were positive for all 3 viruses (HPV, MBV and WSSV), 1 (1\%) was positive for HPV and MBV, 1 (1\%) was positive for HPV and WSSV, and 20 (19\%) were positive for WSSV and MBV. MBV alone was detected in 10 samples (9\%), and WSSV alone in 27 samples (25\%), while no viruses were detcted in 17 samples $(16 \%)$. These results indicate not only a high prevalence of all the 3 viruses in Penaeus monodon PL in India, but also a high prevalence of concurrent viral infections that usually include HPV. A significant number of samples (22\% of hatchery samples and $19 \%$ of farmer samples) also showed dual infections of MBV and WSSV, as reported earlier by Otta et al. (2003). The presence of concurrent viral infections causing mortality in $P$. monodon PL has also been recorded by Manivannan et al. (2002). Thus, it is concluded that screening of PL for all these viruses is essential before stocking of culture ponds.

The presence of multiple viruses may impact the health of Penaeus monodon PL. The observation that infection with HPV alone occurs in only a small percentage $(2 \%)$ of $P$. monodon PL may be significant. Similarly, infection with MBV alone was observed in only $8 \%$ of hatchery samples and $9 \%$ of samples submitted by farmers, while infection with WSSV alone was found in $27 \%$ of hatchery samples and $25 \%$ of samples submitted by farmers (Tables $3 \& 4$ ). The results suggest that HPV and MBV are mostly found as components of multiple viral infections, while WSSV is more frequently found alone. 
Table 3. Penaeus monodon. Prevalence of multiple viral infections detected by PCR in hatchery-reared PL of $P$. monodon in India. HPV: hepatopancreatic parvovirus; MBV: monodon baculovirus; WSSV: white spot syndrome virus

\begin{tabular}{|c|c|c|c|c|c|c|c|c|}
\hline $\begin{array}{l}\text { Total } \\
\text { no. } \\
\text { samples } \\
\text { analyzed }\end{array}$ & $\begin{array}{c}\text { No. positive } \\
\text { for HPV, } \\
\text { MBV } \\
\text { and WSSV }\end{array}$ & $\begin{array}{c}\text { No. positive } \\
\text { for HPV } \\
\text { and } \\
\text { MBV }\end{array}$ & $\begin{array}{c}\text { No. positive } \\
\text { for HPV } \\
\text { and } \\
\text { WSSV }\end{array}$ & $\begin{array}{c}\text { No. positive } \\
\text { for MBV } \\
\text { and } \\
\text { WSSV }\end{array}$ & $\begin{array}{l}\text { No. } \\
\text { positive } \\
\text { for } \\
\text { HPV }\end{array}$ & $\begin{array}{l}\text { No. } \\
\text { positive } \\
\text { for } \\
\text { MBV }\end{array}$ & $\begin{array}{l}\text { No. } \\
\text { positive } \\
\text { for } \\
\text { WSSV }\end{array}$ & $\begin{array}{c}\text { No. negative } \\
\text { for } \\
\text { HPV, MBV } \\
\text { and WSSV }\end{array}$ \\
\hline 95 & $\begin{array}{c}26 \\
(27 \%)\end{array}$ & $\begin{array}{c}1 \\
(1 \%)\end{array}$ & $\begin{array}{c}3 \\
(3 \%)\end{array}$ & $\begin{array}{c}21 \\
(22 \%)\end{array}$ & $\begin{array}{c}2 \\
(2 \%)\end{array}$ & $\begin{array}{c}8 \\
(8 \%)\end{array}$ & $\begin{array}{c}26 \\
(27 \%)\end{array}$ & $\begin{array}{c}8 \\
(8 \%)\end{array}$ \\
\hline
\end{tabular}

Table 4. Penaeus monodon. Prevalence of multiple viral infections detected by PCR in samples of PL submitted by farmers from different coastal states. HPV: hepatopancreatic parvovirus; MBV: monodon baculovirus; WSSV: white spot syndrome virus

\begin{tabular}{|c|c|c|c|c|c|c|c|c|}
\hline $\begin{array}{l}\text { Total } \\
\text { no. } \\
\text { samples } \\
\text { analyzed }\end{array}$ & $\begin{array}{c}\text { No. positive } \\
\text { for HPV, } \\
\text { MBV } \\
\text { and WSSV }\end{array}$ & $\begin{array}{c}\text { No. positive } \\
\text { for HPV } \\
\text { and } \\
\text { MBV }\end{array}$ & $\begin{array}{c}\text { No. positive } \\
\text { for HPV } \\
\text { and } \\
\text { WSSV }\end{array}$ & $\begin{array}{c}\text { No. positive } \\
\text { for MBV } \\
\text { and } \\
\text { WSSV }\end{array}$ & $\begin{array}{l}\text { No. } \\
\text { positive } \\
\text { for } \\
\text { HPV }\end{array}$ & $\begin{array}{l}\text { No. } \\
\text { positive } \\
\text { for } \\
\text { MBV }\end{array}$ & $\begin{array}{l}\text { No. } \\
\text { positive } \\
\text { for } \\
\text { WSSV }\end{array}$ & $\begin{array}{c}\text { No. negative } \\
\text { for } \\
\text { HPV, MBV } \\
\text { and WSSV }\end{array}$ \\
\hline 107 & $\begin{array}{c}31 \\
(29 \%)\end{array}$ & $\begin{array}{c}1 \\
(1 \%)\end{array}$ & $\begin{array}{c}1 \\
(1 \%)\end{array}$ & $\begin{array}{c}20 \\
(19 \%)\end{array}$ & $\begin{array}{c}0 \\
(0 \%)\end{array}$ & $\begin{array}{c}10 \\
(9 \%)\end{array}$ & $\begin{array}{c}27 \\
(25 \%)\end{array}$ & $\begin{array}{c}17 \\
(16 \%)\end{array}$ \\
\hline
\end{tabular}

Acknowledgements. The financial support of the Indian Council of Agricultural Research under the National Agricultural Technology Programme (NATP-CGP) is gratefully acknowledged. The Thermocylcer and electrophoresis power pack used in the study were donated by the Alexander von Humboldt Foundation, Germany.

\section{LITERATURE CITED}

Belcher CR, Young PR (1998) Colourimetric PCR based detection of monodon baculovirus in whole Penaeus monodon postlarvae. J Virol Methods 74:21-29

Chakraborty A, Otta SK, Joseph B, Sanath Kumar H, Hossain Md S, Karunasagar I, Venugopal MN, Karunasagar I (2002) Prevalence of white spot syndrome virus in wild crustaceans along the coast of India. Curr Sci 82 (11):1392-1397

Chong YC, Loh H (1984) Hepatopancreas chlamydial and parvoviral infections of farmed marine prawns in Singapore. Singapore Vet J 9:51-56

Flegel TW, Thamavit V, Pasharawipas T, Alday-Sanz V (1999) Statistical correlation between severity of hepatopancreatic parvovirus (HPV) infection and stunting of farmed black tiger shrimp (Penaeus monodon). Aquaculture 174: 197-206

Hossain Md S, Chakraborty A, Joseph B, Otta SK, Karunasagar I, Karunasagar I (2001) Detection of new hosts for white spot syndrome virus of shrimp using nested polymerase chain reaction. Aquaculture 198:1-11

Hsu YL, Wang KH, Yang YH, Tung MC, Hu CH, Lo CF, Wang CH, Hsu T (2000) Diagnosis of Penaeus monodon-type baculovirus by PCR and by ELISA of occlusion bodies. Dis Aquat Org 40:93-99

Lightner DV (1993) Diseases of penaeid shrimp. In: McVey JP (ed) CRC handbook of mariculture, 2nd edn. Vol 1, Crustacean aquaculture. CRC Press, Boca Raton, FL, p 393-486

Lightner DV (ed) (1996) A handbook of pathology and diagnostic procedures for diseases of penaeid shrimp. World

Editorial responsibility: Timothy Flegel,

Bangkok, Thailand
Aquaculture Society, Baton Rouge, LA

Lightner DV, Redman RM (1985) A parvo-like virus disease of penaeid shrimp. J Invertebr Pathol 45:47-53

Lin CK (1989) Prawn culture in Taiwan. What went wrong? World Aquac 20:19-20

Lo CF, Leu JH, Ho CH, Chen CH and 8 others (1996) Detection of baculovirus associated with white spot syndrome (WSBV) in penaeid shrimps using polymerase chain reaction. Dis Aquat Org 25:133-141

Manivannan S, Otta SK, Karunasagar I, Karunasagar I (2002) Multiple viral infection in Penaeus monodon shrimp postlarvae in an Indian hatchery. Dis Aquat Org 48:233-236

Nash G, Anderson IG, Shariff M (1988) Pathological changes in the tiger prawn Penaeus monodon Fabricius, associated with culture in brackish water ponds developed from potentially acid sulphate soils. J Fish Dis 11:113-123

Otta SK, Shubha G, Joseph B, Chakraborty A, Karunasagar I, Karunasagar I (1999) Polymerase chain reaction (PCR) detection of white spot syndrome virus (WSSV) in cultured and wild crustaceans in India. Dis Aquat Org 38:67-70

Otta SK, Karunasagar I, Karunasagar I (2003) Detection of monodon baculovirus and whitespot syndrome virus in apparently healthy Penaeus monodon postlarvae from India by polymerase chain reaction. Aquaculture 220:59-69

Pantoja CR, Lightner DV (2000) A non-destructive method based on the polymerase chain reaction for detection of hepatopancreatic parvovirus (HPV) of penaeid shrimp. Dis Aquat Org 39:177-182

Phromjai J, Boonsaeng V, Withyachumnarnkul B, Flegel TW (2002) Detection of hepatopancreatic parvovirus in Thai shrimp Penaeus monodon by in situ hybridization, dot blot hybridization and PCR amplification. Dis Aquat Org 51: $227-232$

Ramasamy P, Brennan GP, Jayakumar R (1995) A record and prevalence of monodon baculovirus from postlarval Penaeus monodon in Madras, India. Aquaculture 130:129-135

Thikiew N (1990) A serious MBV outbreak in the black tiger prawn. Livestock Production Magazine 7(151):13-16 (in Thai)

Submitted: April 10, 2003; Accepted: July 31, 2003

Proofs received from author(s): September 8, 2003 